\title{
Physiochemical Properties, Volatile Compounds and Sensory Evaluation of Chili Sauce Shrimp Paste from Different Regions in Indonesia
}

\author{
Wildan Suhartini, Fang Yang, Wenshui Xia* \\ State Key Laboratory of Food Science and Technology, School of Food Science and Technology, Jiangnan University, Wuxi, China \\ Email: *xiaws@jiangnan.edu.cn
}

How to cite this paper: Suhartini, W., Yang, F. and Xia, W.S. (2019) Physiochemical Properties, Volatile Compounds and Sensory Evaluation of Chili Sauce Shrimp Paste from Different Regions in Indonesia. Food and Nutrition Sciences, 10, 333-348. https://doi.org/10.4236/fns.2019.103026

Received: March 6, 2019

Accepted: March 25, 2019

Published: March 28, 2019

Copyright $\odot 2019$ by author(s) and Scientific Research Publishing Inc. This work is licensed under the Creative Commons Attribution International License (CC BY 4.0).

http://creativecommons.org/licenses/by/4.0/ (c) (i) Open Access

\begin{abstract}
Chili sauce shrimp paste (CSSP) is an exotic traditional sauce prepared using mainly fresh chili and shrimp paste well known as sambal terasi (Indonesia) and sambal belacan (Malaysia and Brunei). This study aims to evaluate CSSP from different regions in Indonesia on physiochemical properties, volatile compounds, and sensory evaluation. Evaluation in free amino acid (FAA) and volatile compounds were analyzed using HPLC and GC-MS. CSSP had no significant $(p>0.05)$ on proximate (except for moisture), salinity, $\mathrm{pH}$, microbial counts and the redness index $\left(a^{*} b^{*}\right)$ compared to control. The identified volatiles can be grouped into hydrocarbon, carbonyl, sulfur, alcohol, nitrogen, fatty acid, and ester compounds. The CSSP A, B, C, D, and E (control) contained 9, 21, 12, 29, and 6 volatile compounds respectively. The total FAA ranged from 44.32 to $67.03 \mathrm{~g} / 100 \mathrm{~g}$, and histidine (his) was found as the most abundant in each CSSP. The rheological properties (yield stress, viscosity, and consistency) of CSSP and control values were significantly, except for CSSP B. The intensities perceived of saltiness, sweetness, and bitterness were greatly varied among CSSP. Although there is no correlation between sweetness and bitterness this is indicated by the negative correlation.
\end{abstract}

\section{Keywords}

Chili Sauce Shrimp Paste, Volatile Compound, Rheological Properties, Sambal Terasi, Free Amino Acid

\section{Introduction}

Chili sauce shrimp paste (CSSP) is an exotic traditional Southeast Asian sauce 
condiment prepared using mainly fresh chilies and shrimp paste [1] [2] well known as sambal terasi (Indonesia), sambal belacan (Malaysia and Brunei. Shrimp paste known by different names such as terasi (Indonesia), nappi (Bangladesh), kapi (Thailand and Cambodia), belacan (Malaysia and Brunei), shajiang (China), jeotgall jeo (Korea), bagoong-alamang (Philippines), mam ruoc or mam tom (Vietnam), and hmyinnga-pi (Myanmar) [3]. Shrimp paste is one of the most common methods of shrimp preservation on the Asian countries [4] which attributed to strong and pungent fishy odor [2].

The raw material of fermented shrimp paste used the planktonic shrimps of genera; Acetes, Mesopodopsis, Lucifer, and Mysids are usually [5]. The genus Acetes, species of japonicas, vulgaris and erythraeus are the most common raw material to produce fermented shrimp in Southeast Asian countries, locally known as rebon in Indonesia and geragau in Malaysia and Brunei [6]. Shrimp paste involves the use of high salt concentration and incubation at ambient temperature [7], and the major processing is salting, fermenting, and aging. Shrimp paste has radish brown to blackish brown color depending on the raw materials and the naturally occurring microbes which involve during fermentation [2], a strong distinctive smell or odor which upon heating or cooking releases volatile compounds [8]. Shrimp paste from different regions have not the same odor, color, nutritional, and amino acid as a result of processing variety such as length of sun exposure for drying and of fermentation time [5] [9]. Shrimp paste has considerable level of free glutamic acid, amino acid and rich in umami taste [10]. Different regions have different recipes of chili sauce shrimp paste (CSSP) even though with a same combination of various ingredients. Fermented shrimp paste has been used for countries as a flavoring on dishes [11].

The use of additional ingredients, with specific functionality may therefore help in modulating CSSP properties, sensory attributes, and stability as well as to product tailor which made product for specific application (i.e. multicomponent and complex product) [12] [13]. To meet consumers quality requirements, some quality parameters and shelf-life of CSSP products are to be considered important such as chemical qualities, microbial, and also rheological and appearance indicators (i.e. consistency and color) [14]. However, so far the study on the potential of shrimp paste as chili sauce fortification from different regions in Indonesia has not been carried out. This study was conducted to formulation and process improvement for chili sauce shrimp paste based on physiochemical properties, volatile compounds, and sensory evaluation. Therefore, the objectives of this study were to 1) investigate the feasibility of chili sauce fortification using fermented shrimp paste, 2) determine the physiochemical properties, 3) evaluate volatile compounds, and 4) evaluate the sensory attributes of CSSP.

\section{Materials and Methods}

\subsection{Materials}

The shrimp of genera Acetes, locally known as rebon (Indonesia) was purchased 
from four different regions in Indonesia. Whole part of the shrimp and salt was used to fermentation in this study. Ingredients for chili sauce shrimp paste (CSSP) preparation i.e. chili (Capsicum annum), sugar, oil, shrimp paste, salt, monosodium glutamate as flavor enhancer, modified starch, preservative potassium sorbet, and kalamansi as acid source were all of food grade obtained from local wholesale market in Wuxi, Jiangsu, China.

\subsection{Processing of Shrimp Paste}

Four different types of shrimp paste production from different regions in Indonesia. They were codes as A (from Jakarta), B (from West java), C (from Central Java), and D (from East Java). In the processing of fermented shrimp, firstly fresh shrimp is washed, drained and dried until half dried. During drying, impurities such as small fish, mussel shells and coral are removed. After that, semi dried shrimp is sifted to spare to separate sand and other undesirable materials. The shrimp is then left overnight at ambient temperature and pounded the next day. During the first pounding salt is added (around half of the total salt required during processing). Total amount of salt used in shrimp fermentation processing is $20 \%$ of shrimp weight which should be added as solution. Pounded shrimp is oven dried and subsequently kept in a container at ambient temperature for $2-3$ days. The stored shrimp is then pounded for a second time, while the remaining salt is added. After that, the pounded shrimp is oven dried and kept at ambient temperature for 3 - 5 weeks until soft. It is the ground by many passes through a meat grinder until fine [15].

\subsection{Preparation and Production of CSSP}

A formulation of chili sauce shrimp paste (CSSP) was developed in the laboratory. The basic recipes were obtained from regions where shrimp samples are taken and the basic recipes are the same. The stem of the chilies were removed before washing. The chilies were drained to remove excess water. The shrimp paste was heated in the oven at $100^{\circ} \mathrm{C}$ for $10 \mathrm{~min}$. This grilled step is critical for flavor which will result in a flavorful CSSP. Kalamansi were cut into half and the juice was squeezed from the fruit. All ingredients were ground using food processor (Philips-HR7776) for $15 \mathrm{~min}$, then fried in low heat for 30 minutes. The chili sauce shrimp paste was ready for analysis. CSSP was codes accordance to code of shrimp paste which are A (for shrimp paste from Jakarta), B (for shrimp paste from West Java), C (for shrimp paste from Central Java), D (for Shrimp paste from East Java) and $\mathrm{E}$ is control (without shrimp paste).

\subsection{Physiochemical Analysis}

Moisture content, protein, fat, ash, and carbohydrate content were analyzed according to Association Official of Analytical Chemists (AOAC 2000) [16]. The $\mathrm{pH}$ of chili sauce shrimp paste (CSSP) was measured using a digital bench top pH meter (Mettler Toledo ${ }^{\text {TM }}$ FE20 FiveEasy ${ }^{\text {TM }}$, Schwerzenbach, Switzerland) 
[17]. Sodium content was determined by Mohr titration method. By knowing the amount of chloride ions that need to be titrated with $\mathrm{AgNO}_{3}$ will find the sodium ions content of CSSP [18].

Volatile compounds of CSSP was analyze with a gas chromatograph-mass spectrometer (GC-MS). Deodorized distilled water was by boiling glass-distilled water to two-thirds of its original volume. A mixture $35 \mathrm{~g}$ of CSSP and $315 \mathrm{ml}$ of deodorized distilled water was homogenized using a blender (Joyoung JYL-C012, China) at low speed for $3 \mathrm{~min}$. Five $\mathrm{ml}$ of the mixture was placed in the $20 \mathrm{ml}$ headspace vial. Vial was heated at $80^{\circ} \mathrm{C}$ for $45 \mathrm{~min}$ while shaking at high speed using headspace sampler. Sample was transferred to a gas chromatograph (GC-2010, Shimadzu, Kyoto, Japan) for separation. The loop and transfer line temperature were $90^{\circ} \mathrm{C}$ and $100^{\circ} \mathrm{C}$ respectively. The injector temperature was maintained at $250^{\circ} \mathrm{C}$. For identification, the gas chromatograph was coupled to a mass spectrometer.

Free amino acid (FAA) was determination performed base on the method followed in the key laboratory of food science and technology, Jiangnan University, Wuxi, Jiangsu, China. CSSP sample $1 \mathrm{~g}$ weighed into tubes and hydrolyzed in $8 \mathrm{ml} 5 \mathrm{M} \mathrm{NaOH}$ in alkaline hydrolysis tube containing sample, then treatment by nitrogen filling in $3 \mathrm{~min}$, put the tube into the oven for $22 \mathrm{~h}$ at $105^{\circ} \mathrm{C}$. Transferred the sample from the tube to the $25 \mathrm{ml}$ volumetric flask and added $6.67 \mathrm{ml}$ $6 \mathrm{M} \mathrm{HCl}$. Washed the wall of the flask by small amount of water, then diluted with water to $25 \mathrm{ml}$, after that filtrated out of 2 slices filter paper. Taken $1 \mathrm{ml}$ of filtrate and centrifuged at 10,000 rpm for $10 \mathrm{~min}$. Taken $400 \mu \mathrm{l}$ of the supernatant into HPLC sample bottle. Net height of each peak representing individual FAA produced by chart in recorder of analyzer were measured, calculated, and recorded. Values of FAA were reported as g/100 g of sample. Twenty amino acid for FAA determination with IUPAC symbol i.e. aspartic acid (asp), glutamic acid (glu), asparagine (asn), serine (ser), glutamine (gln), histidine (his), glycine (gly), threonine (thr), citruline (cit), arginine (arg), alanine (ala), tyrosine (tyr), valine (val), methionine (met), tryptophan (trp), phenylalanine (phe), isoleucine (ile), leucine (leu), and lysine (lys), proline (pro) and internal standard (norvaline and sarcosine) were HPLC grade.

\subsection{Microbial Analysis}

Microbiological evaluation of CSSP was carried out immediately after storage treatment, sample were analyzed for the aerobic plate count (APC). The determination of APC was done using the pour-plate method on plate count agar in accordance to the ISO 4833:2003 standard protocol [19].

\subsection{Rheological Properties}

The rheological characterization of CSSP were investigated using a rheometer (Discovery $^{\mathrm{HR}-3}$, hybrid rheometer, TA instrument, UK) connected to computing applications (TRIOS). Serrated plates are measured according to geometry PP35S 
to avoid slippage. Oscillation frequency sweep tests applied in the frequency range from 1.00 to $30.00 \mathrm{~Hz}$ with a shear stress of $50.00 \mathrm{~Pa}$ at $25^{\circ} \mathrm{C} \pm 0.1^{\circ} \mathrm{C}$ and the loss tangent values in $20 \mathrm{~Hz}$ were used for paste preference evaluating.

\subsection{Color Properties}

The color of CSSP sample was measured using a UltraScan PRO $5 \mathrm{~nm}$ optical resolution at wavelength range from 250 to $1100 \mathrm{~nm}$ (Hunter Associate Laboratory Inc., Reston, USA). Easy Match QC software is attached to the equipment. The ultraScan PRO measures the reflected color of food products, measured color represented by Hunter's color value, $L$ (lightness), $a$ (redness), and $b$ (yellowness). The instrument was calibrated on a white standard tile before analysis $\left(L^{*}=98.82 ; a^{*}=-0.18 ; b^{*}=0.31\right)$.

\subsection{Sensory Evaluation}

Twenty-one (21) semi-trained panelists are Indonesian living in Wuxi, Jiangsu, China, the age of panelist between 18 - 40 years old. These panelists had received a brief explanation of each of the sensory attributes (Table 5). Intensity evaluation of the perception by the panel was carried out by use of unstructured linear scale with the anchor point 0 -not perceptible and 10-strongly perceptible. The chili sauce shrimp paste (CSSP) was put in the glass bottle container, and samples were coded with three digit random numbers to storage in refrigerator $\left(4^{\circ} \mathrm{C}\right)$. Duplicate samples were served each panelist in different seasons in a randomized order. Mineral water was provided to cleanse the palate between samples during evaluation. The study was performed in tasting booths with properly controlled environment conditions [20].

\subsection{Statistical Analysis}

Statistical analysis for physiochemical, microbial, rheological, color, and sensory analysis of different chili sauce shrimp paste (CSSP) was performed using two-way analysis of variance (ANOVA) and Duncan test to determine the significant difference among means at the level of $p=0.05$ using statistical package of SPSS version 16 (SPSS Inc., Chicago).

\section{Results and Discussion}

\subsection{Physiochemical Properties of CSSP}

The proximate composition of CSSP is shown in Table 1. The fat and moisture content of the CSSP tended to be higher in CSSP than control $(p<0.05)$. The protein, moisture, ash and carbohydrate content of CSSP compared to control was no significant $(p>0.05)$. However, the result of this study was in agreement with the previous study that traditional chili shrimp paste in Malaysia indicated approximately $70 \%$ moisture content [21], the percentage of fat in CSP is around $0.41 \%$ and the protein content is around $7.67 \%$ [22].

The CSSP and control had $\mathrm{pH}$ range of $5.73-6.40$, shown in Table 1 that no 
Table 1. Physiochemical properties of CSSP and control.

\begin{tabular}{cccccccc}
\hline \multirow{2}{*}{ Sample } & \multicolumn{5}{c}{ Proximate (\%) } & Salinity (\%) & pH \\
\cline { 2 - 7 } & Fat & Protein & Moisture & Ash & Carbohydrate & & \\
\hline A & $5.00^{\mathrm{a}}$ & $6.00^{\mathrm{a}}$ & $68.34^{\mathrm{a}}$ & $12.73^{\mathrm{a}}$ & $9.07^{\mathrm{a}}$ & $3.01^{\mathrm{a}}$ & $6.40^{\mathrm{a}}$ \\
B & $2.09^{\mathrm{b}}$ & $1.90^{\mathrm{b}}$ & $70.06^{\mathrm{a}}$ & $13.96^{\mathrm{a}}$ & $5.00^{\mathrm{b}}$ & $3.92^{\mathrm{a}}$ & $6.29^{\mathrm{a}}$ \\
C & $4.31^{\mathrm{a}}$ & $2.62^{\mathrm{b}}$ & $69.37^{\mathrm{a}}$ & $13.04^{\mathrm{a}}$ & $4.10^{\mathrm{b}}$ & $3.08^{\mathrm{a}}$ & $6.35^{\mathrm{a}}$ \\
D & $4.08^{\mathrm{a}}$ & $1.76^{\mathrm{b}}$ & $70.20^{\mathrm{a}}$ & $10.98^{\mathrm{a}}$ & $2.84^{\mathrm{b}}$ & $4.06^{\mathrm{a}}$ & $6.30^{\mathrm{a}}$ \\
E & $2.11^{\mathrm{b}}$ & $3.25^{\mathrm{ab}}$ & $89.11^{\mathrm{b}}$ & $11.70^{\mathrm{a}}$ & $5.02^{\mathrm{ab}}$ & $4.74^{\mathrm{a}}$ & $5.73^{\mathrm{a}}$ \\
\hline
\end{tabular}

Means with different letters are significantly different $(p<0.05)$ for each parameter (column).

significant $(p>0.05)$ between CSSP and control. However, $\mathrm{pH}$ of CSSP decreased compared to $\mathrm{pH}$ of shrimp paste which had $\mathrm{pH} 7.62$ for Indonesian dried shrimp paste, and pH 6.83 - 7.23 for Korean dried shrimp paste [3]. Kalamansi (Citrfortunella microcarpa) as acid sources of CSSP had dominant organic acid and it impart as a tangy citrus flavor [23], that might decreased $\mathrm{pH}$ in the final product. The salinity of CSSP had no significant $(p>0.05)$ compared to control, even though control had salinity of $4.74 \%$, which was higher than CSSP (3.01\% - 4.06\%). In general, salinity of chili shrimp paste is $4.4 \%$ [21]. The salinity of CSSP depends on the quality and type of salt used during manufacturing process [24].

\subsubsection{Volatile Compounds}

The chromatogram of GC-MS result was dentified based on the retention time and the area of the peaks (Figure 1). Table 2 showed the result of each class of volatile compounds in each CSSP containing shrimp paste from different area. The identified volatiles can be grouped into hydrocarbon, carbonyl, sulfur, alcohol, nitrogen, fatty acid, and ester compounds which showed similarities with other research volatile compounds of shrimp paste [25] [26]. The CSSP A, B, C, $\mathrm{D}$, and $\mathrm{E}$ (control) are contained 9, 21, 12, 29, and 6 volatile compounds respectively. Sample E (control) has the lowest and CSSP D has the highest of volatile compounds. Dimethyl sulfide as an organosulfur which are formed from the degradation of methionine (met) amino acid in food product [27]. This volatile compound have cabbage aroma respectively. Alcohol and aldehydes are an important role in chilies flavor [28], and conferring the freshness of products [29]. Ester usually provides the aroma of food with fruity notes [30].

\subsubsection{Free Amino Acid (FAA)}

The free amino acid (FAA) content of CSSP is shown in Figure 2. The FAA content of CSSP and control ranged from 44.32 to $67.03 \mathrm{~g} / 100 \mathrm{~g}$ respectively. His was found as the most abundant and varied FAA in each CSSP, which consisting more than $15 \%$ of total FAA, followed by asp, met, and lys. Lys tended to be dominant in the long fermented fish product [31]. These result are comparable to fish sauce production in Southeast and East Asian countries, as asp, glu, and 
Table 2. Volatile compounds in chili sauce shrimp paste (CSSP) and control.

\begin{tabular}{|c|c|c|c|c|c|}
\hline Compound & A & $\mathrm{B}$ & $\mathrm{C}$ & $\mathrm{D}$ & $\mathrm{E}$ \\
\hline \multicolumn{6}{|l|}{ Hydrocarbon } \\
\hline Hexadecane & + & + & + & + & + \\
\hline 1,4-octadiene & + & - & - & - & - \\
\hline 7-hexadecane & + & + & + & - & - \\
\hline 1,11-dodecadiene & + & + & + & + & - \\
\hline 2-Methylbutylidene 2-phenylethyl & - & + & - & - & + \\
\hline Cyclododecane & - & - & - & - & - \\
\hline 3-Tetradecene & - & - & + & - & - \\
\hline 1.3-cyclooctadicene & - & + & - & + & - \\
\hline 1-pentadecene & - & - & - & + & - \\
\hline Cyclotetradecene & - & + & - & + & - \\
\hline Cyclodecene & - & - & - & + & - \\
\hline 1,2-dimethyl cyclooctane & - & - & - & + & - \\
\hline Bicyclo [2.2.1] heptane & - & - & - & + & - \\
\hline 1.4-cyclononadiene & - & + & - & - & - \\
\hline 2-metoxy naphthalene & - & - & - & + & - \\
\hline Subtotal & 4 & 7 & 4 & 10 & 2 \\
\hline \multicolumn{6}{|l|}{ Carbonyl } \\
\hline $5 z, 8 z, 11 z$-tetra-decatrien-2-one & + & - & - & + & - \\
\hline 2-Undecanon & - & - & - & + & - \\
\hline 2-Tridecanon & - & - & - & + & - \\
\hline 1-Finil-Etenon & - & - & - & + & - \\
\hline Benzaldehyde & - & + & - & - & - \\
\hline 3,4,5-methyl Cyclopentene-1-one & - & + & - & - & - \\
\hline Subtotal & 1 & 2 & 0 & 4 & 0 \\
\hline \multicolumn{6}{|l|}{ Sulfur } \\
\hline Dimethyl trisulfide & - & + & + & + & - \\
\hline Dinonil trisulfide, isomer mix & - & + & - & - & - \\
\hline Subtotal & 0 & 2 & 1 & 1 & 0 \\
\hline \multicolumn{6}{|l|}{ Alcohol } \\
\hline Phenol, 2,6-bis (1,1-dimethylethyl) & + & + & - & + & - \\
\hline Phenol & + & + & - & + & + \\
\hline 1-pentadecanol & + & - & - & - & - \\
\hline Phenyl ethyl alcohol & - & - & + & - & - \\
\hline 2.2-oxibis Ethanol & - & - & + & - & - \\
\hline 4-methyl phenol & - & + & - & + & - \\
\hline 1-Heptadecanol & - & - & - & + & - \\
\hline 1-Octadecanol & - & - & - & + & - \\
\hline p-Mentha-1 (7), 8 (10)-dien-9-ol & - & - & - & + & - \\
\hline 9,12,15-octadeca-trien-1-ol & - & - & - & + & - \\
\hline Mentionol & - & + & - & - & - \\
\hline
\end{tabular}




\section{Continued}

\begin{tabular}{|c|c|c|c|c|c|}
\hline Subtotal & 3 & 4 & 2 & 7 & 1 \\
\hline \multicolumn{6}{|l|}{ Nitrogen } \\
\hline Indole & + & + & + & + & + \\
\hline 2.6-dimethyl-3-N-butilpyrazine & - & - & - & + & - \\
\hline 2.6-dimethyl pirazin & - & - & - & + & - \\
\hline 2,5-dimethyl-3-(3-methyl) pirazin & - & + & - & - & - \\
\hline 4-Phenyl Piridine & - & - & - & + & - \\
\hline 4-methyl-2-phenyl pyrimidine & - & - & - & + & - \\
\hline Benzeamine & - & + & - & - & - \\
\hline 1-Benzeneetamine, $\mathrm{N}$-(Fenilmetil) & - & + & - & - & - \\
\hline 5-metiloxiindol & - & + & - & - & - \\
\hline Subtotal & 1 & 5 & 1 & 5 & 1 \\
\hline \multicolumn{6}{|l|}{ Fatty acid } \\
\hline 1,2 Benzene-dicarboxylic acid & - & - & + & - & - \\
\hline Pentanoic acid & - & - & + & - & - \\
\hline Hexadecanoic acid & - & - & - & + & - \\
\hline Tetradecanoic acid & - & + & - & - & - \\
\hline Subtotal & - & 1 & 2 & 1 & 0 \\
\hline \multicolumn{6}{|l|}{ Ester } \\
\hline Hexadecanoic acid, Methyl ester & - & - & + & - & - \\
\hline Ethyl linoleic & - & - & - & + & - \\
\hline Total & 9 & 21 & 11 & 29 & 6 \\
\hline
\end{tabular}

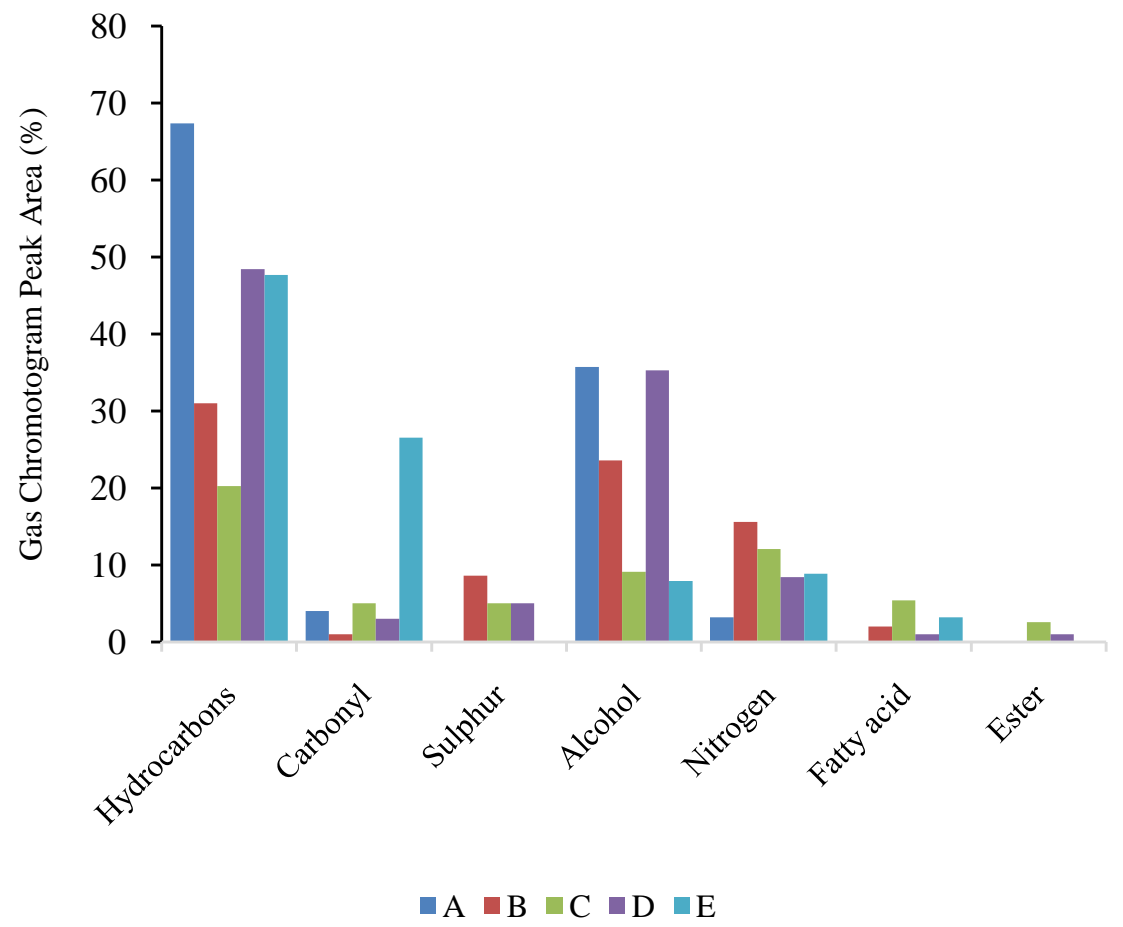

Figure 1. Chromatogram peak area (\%) of each CSSP and control volatile compounds. 


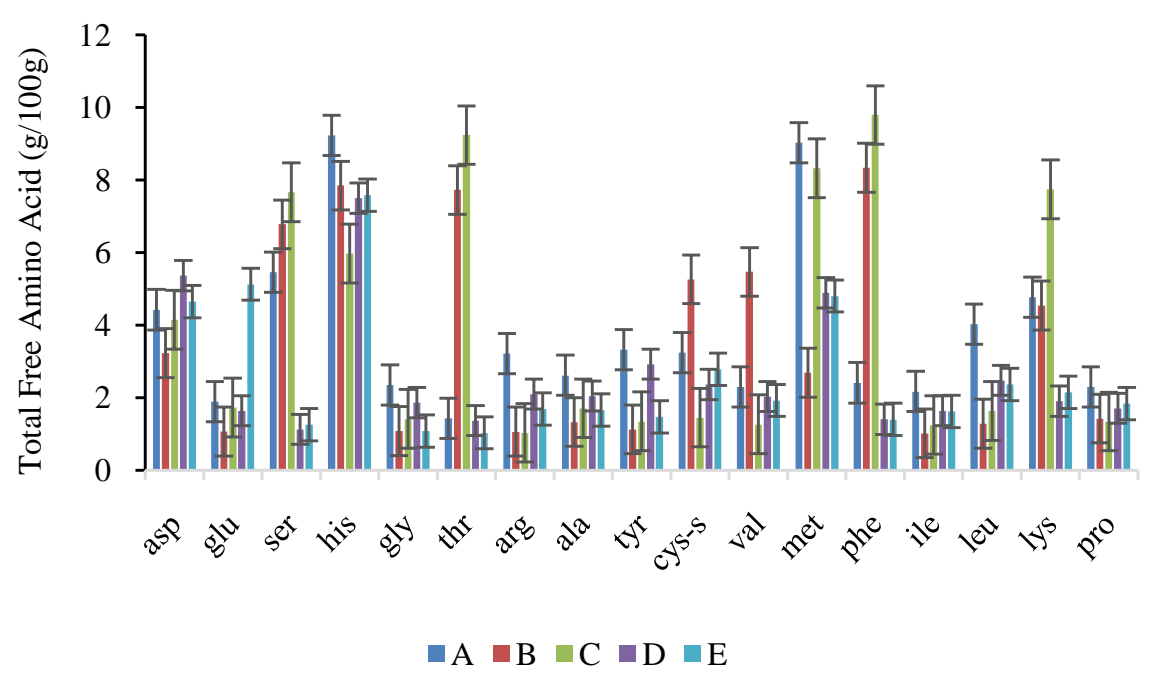

Figure 2. Free Amino Acid (FAA) profile of each CSSP and control (g/100 g).

lys are more the most abundant FAA [32], glu, ala, and ieu are predominantly found in shrimp sauce [33]. Asp, ser, arg, thr, pro val, iso, and lys are related to taste and flavor. Free amino acid related to sweetness are gly, ala, ser, thr, and tyr, while the related to bitterness are val, met, iso, leu, try, phe, his, and arg [34]. The proportion of FAA related to flavor/taste was similar for each CSSP.

\subsection{Microbial Analysis}

The observation of the microbial count (total plate count and yeast and mold) of CSSP and control is shown in Table 3. The results showed that microbial counts of CSSP no significant $(p>0.05)$ in all sample of CSSP compared to control. However, the total plate count (TPC) which is the highest is CSSP C and the lowest is CSSP B, colony count of yeast and mold the highest is CSSP D and the lowest is CSSP C. However, to reduce microbial growth for extending the shelf life of food product to an acceptable level of microorganism, chemical and physical methods can be used [35]. Chemical methods usually used such as dimethyl dicarbonate (DMDC), sodium metabisulfite, sodium benzoate, and potassium sorbate. DMDC is not a suitable processing aid to be used for microbial reduction in a fat containing food system such as CSSP [36]. On the other hand, using 300 ppm sodium hypochlorite $(\mathrm{NaOCl})$ with acetic acid in the ratio 1:1 for $10 \mathrm{~min}$ in spice products considers less production time, less amount of acetic acid usage and higher microbial reduction [35].

Physical methods to reduce microbial growth of food product are used such as irradiation treatment. Electron beam irradiation at $10 \mathrm{kGy}$ is an effective irradiation dose in reaching good level decontamination in chili shrimp paste for total pathogenic enterobacteriaceae, mesophilic bacteria, yeast and mold [2], another research reported that electron beam irradiation of $3.0 \mathrm{kGy}$ on sun-dried apricots was sufficient to suppress the growth of yeast and mold, and bacterial to below detection limits for a storage for 10 months [37]. On the other hand, physical methods cannot always be applied owing restriction such as temperature safety 
Table 3. Microbial count and rheological properties of CSSP and control.

\begin{tabular}{cccccc}
\hline & \multicolumn{2}{c}{ Microbial count } & \multicolumn{3}{c}{ Rheological properties } \\
\cline { 2 - 6 } Sample & $\begin{array}{c}\text { TPC } \\
(\mathrm{CFU} / \mathrm{mL})\end{array}$ & $\begin{array}{c}\text { Yeast and Mold } \\
(\mathrm{CFU} / \mathrm{mL})\end{array}$ & $\begin{array}{c}\text { Yield stress, } \tau_{0} \\
(\mathrm{~Pa})\end{array}$ & $\begin{array}{c}\text { Viscosity }(\mathrm{Pa} \cdot \mathrm{s}) \\
\text { Consistency, } \\
\text { K }\left(\mathrm{Pa} \cdot \mathrm{s}^{\mathrm{n}}\right)\end{array}$ \\
\hline A & $2.3 \times 10^{3}$ & $3.9 \times 10^{2}$ & $1657.63 \pm 1.43^{\mathrm{a}}$ & $20.20 \pm 0.01^{\mathrm{a}}$ & $978.64 \pm 0.13^{\mathrm{a}}$ \\
B & $1.1 \times 10^{3}$ & $4.0 \times 10^{2}$ & $763.89 \pm 0.09^{\mathrm{b}}$ & $8.62 \pm 0.30^{\mathrm{b}}$ & $512.76 \pm 0.02^{\mathrm{b}}$ \\
C & $4.2 \times 10^{3}$ & $2.7 \times 10^{2}$ & $1796.72 \pm 0.65^{\mathrm{a}}$ & $21.34 \pm 0.09^{\mathrm{a}}$ & $1109.07 \pm 0.04^{\mathrm{a}}$ \\
D & $3.5 \times 10^{3}$ & $4.2 \times 10^{2}$ & $1495.12 \pm 0.13^{\mathrm{a}}$ & $18.40 \pm 0.01^{\mathrm{a}}$ & $692.49 \pm 0.09^{\mathrm{a}}$ \\
E & $1.6 \times 10^{3}$ & $3.7 \times 10^{2}$ & $31.94 \pm 0.66^{\mathrm{b}}$ & $0.35 \pm 0.07^{\mathrm{b}}$ & $32.31 \pm 0.02^{\mathrm{b}}$ \\
\hline
\end{tabular}

All data are expressed as the mean \pm SD from three independent replication. Means with different letters are significantly different $(p<0.05)$ for each parameter (column).

of personnel and design of the process flow [38], considering on chili composition are enriched in essential oil to gives the value of spices, which essential oils are sensitive to temperature.

\subsection{Rheological Properties}

Table 3 showed that the rheological properties (yield stress, viscosity, and consistency) of CSSP and control values were significantly $(p<0.05)$ compared to control (sample E) except for CSSP B and no significant $(p>0.05)$ between samples of CSSP. Viscosity dependence of sauce on pulp or total solids content and naturally occurring pectic substances was already noticed [39] [40]. The sample was heated and mixed for $30 \mathrm{~min}$, generally heated of CSSP for $15 \mathrm{~min}$ [36], processing conditions changed particles shape from spheroidal to elongated leading to greater resistance flow [39]. Yield stress showed that system parameter was dominated by the content of total solid. In comparison to chili shrimp paste (CSP) by processing time for 15 min [2] was characterized by lowest consistency values. For purpose of the standard manufacturing process in industrial conditions on the existing equipment, it was necessary to adjust the consistency of CSSP. This consistency caused that the viscosity of the produced sauce corresponded to the one characteristic for chili sauce, which in the case of independent marketing had to be packed in jars.

\subsection{Color Properties}

The effect different recipes and shrimp paste from four regions in Indonesia on the color of CSSP is shown in Table 4. Shrimp paste and recipes of CSSP have significant impact to the lightness was found in all samples, as compared to control and differ within CSSP samples $(p<0.05)$. CSSP have significant $(p<0.05)$ except for CSSP A in redness, and sample B only in yellowness compared to control was observed. The redness index $\left(a^{*} / b^{*}\right)$ was not affected by the different CSSP with a significantly higher $a^{*} / b^{*}$ in all samples compared to control $(p>$ 0.05).

Redness index enhancement might be associated to a limited alteration of 
Table 4. Color properties of CSSP and control.

\begin{tabular}{ccccc}
\hline Sample & Lightness (L) & Redness (a) & Yellowness (b) & $a^{*} / b^{*}$ \\
\hline A & $32.50 \pm 0.09^{\mathrm{b}}$ & $13.61 \pm 0.11^{\mathrm{b}}$ & $12.32 \pm 0.05^{\mathrm{b}}$ & $1.10 \pm 0.32^{\mathrm{a}}$ \\
B & $29.32 \pm 0.76^{\mathrm{a}}$ & $10.91 \pm 0.23^{\mathrm{a}}$ & $7.63 \pm 0.09^{\mathrm{a}}$ & $1.43 \pm 0.31^{\mathrm{a}}$ \\
C & $32.41 \pm 0.17^{\mathrm{b}}$ & $17.52 \pm 0.06^{\mathrm{c}}$ & $12.91 \pm 0.04^{\mathrm{b}}$ & $1.36 \pm 0.02^{\mathrm{a}}$ \\
D & $33.16 \pm 0.13^{\mathrm{c}}$ & $15.27 \pm 0.32^{\mathrm{d}}$ & $13.54 \pm 0.12^{\mathrm{bc}}$ & $1.13 \pm 0.08^{\mathrm{a}}$ \\
E & $38.23 \pm 0.04^{\mathrm{d}}$ & $13.58 \pm 0.11^{\mathrm{b}}$ & $12.62 \pm 0.44^{\mathrm{b}}$ & $1.08 \pm 0.07^{\mathrm{a}}$ \\
\hline
\end{tabular}

All data are expressed as the mean \pm SD from three independent replication. Means with different letters are significantly different $(p<0.05)$ for each parameter (column).

lycopene during the cooking [41]. The lightness, redness and yellowness of product relate to the food composition, food density, equipment capability as well as packaging materials [42]. Irradiation and thermal treatment had no significantly of chili shrimp paste on color [2].

\subsection{Sensory Evaluation}

The sensory evaluation of CSSP tended to be different (Figure 3) indicating some interaction between shrimp paste and the CSSP. The interaction was probably shown through the correlation among each flavor (Table 5). The intensities perceived of saltiness, sweetness, and bitterness were greatly varied among CSSP. Although there is no correlation between sweetness and bitterness this is indicated by the negative correlation. The highest bitterness from CSSP containing shrimp paste A was probably due to the lowest salt content of CSSP A. $\mathrm{NaCl}$ might elicit sweet, sour, and bitterness, especially at higher concentration [43]. The sea salt has different umami and astringency intensity [44], as salt may contain different concentration of calcium, potassium, magnesium, iron, sodium, and zinc. Food containing seafood has fishy flavor could enhance the saltiness intensity [45]. This is confirmed by the correlation of shrimp flavor which was positively correlated to saltiness, and umami but negatively correlated to the sourness. The free amino acids in shrimp paste were found contributing to the flavor of CSSP.

These free amino acids were also indicated from protein content, which were found to be higher and varied than other major composition of shrimp paste. The major contributor was generally derived from the glutamic acid, alanine, glycine, leucine, and lysine [9]. Some cultures add sour tasting ingredients such as kalamansi to improve the overall flavor of CSSP. The sourness tended to enhance the sweetness of CSSP thereby this sweetness might enhance the umami taste. Umami sometimes linked to sweetness and saltiness [46], along with the actual flavor of compatible food, increase the body or mouthfulness of food, and it makes food taste more pleasant [47]. To suppress the sweetness and bitterness intensity adds chili [48]. Each chili type has its own taste, aftertaste and burning sensation, differentiated by Scoville Heat Units (SHU) [49]. 
Table 5. Spearman Correlation of CSSP and control among each flavor.

\begin{tabular}{ccccccc}
\hline & Sourness & Bitterness & Sweetness & Saltiness & Umami & Shrimp \\
\hline Sourness & 1 & & & & & \\
Bitterness & $0.401^{*}$ & 1 & & & & \\
Sweetness & $0.264^{*}$ & & 1 & & & \\
Saltiness & & $0.426^{*}$ & & 1 & & \\
Umami & $0.301^{*}$ & & $0.347^{*}$ & $0.549^{*}$ & 1 & \\
Shrimp & $0.542^{*}$ & $0.431^{*}$ & & & $0.311^{\star}$ & 1 \\
\hline
\end{tabular}

Correlation is significant at the 0.05 level.
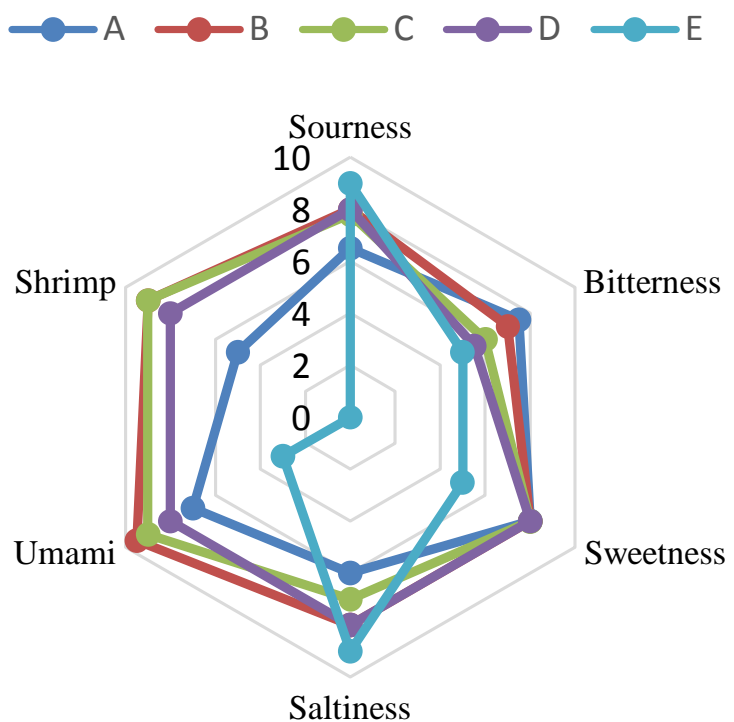

Figure 3. The effect of different type of shrimp paste on the CSSP sensory evaluation.

\section{Conclusion}

Chili sauce shrimp paste from different regions in Indonesia had no significant $(p>0.05)$ in proximate (except for moisture), salinity, and $\mathrm{pH}$. However, the range content is of fat $2.09 \%-5.11 \%$, protein $1.76 \%-6.00 \%$, moisture $68.34 \%$ $89.11 \%$, ash $10.98 \%$ - $13.96 \%$, carbohydrate $2.84 \%-9.07 \%$, and $\mathrm{pH} 5.73-6.40$. The identified volatiles can be grouped into hydrocarbon, carbonyl, sulfur, alcohol, nitrogen, fatty acid, and ester compounds. The CSSP A, B, C, D, and E (control) contained 9, 21, 12, 29, and 6 volatile compounds respectively. The total FAA ranged from 44.32 to $67.03 \mathrm{~g} / 100 \mathrm{~g}$, and histidine (his) was found as the most abundant and varied FAA in each CSSP. The microbial counts and the redness index $\left(a^{*} / b^{*}\right)$ of CSSP are not significant $(p>0.05)$ compared to control. The rheological properties (yield stress, viscosity, and consistency) of CSSP and control values were significantly $(p<0.05)$ except for CSSP B. The intensities perceived of saltiness, sweetness, and bitterness were greatly varied among CSSP. Although there is no correlation between sweetness and bitterness this is indicated by the negative correlation. 


\section{Acknowledgements}

This research was supported by the earmarked fund for China Agriculture Research system (CARS-46), Jiangsu Project for Fisheries, and Collaborative innovation center of food safety and quality control in Jiangsu Province, China.

\section{Conflicts of Interest}

The authors declare no conflicts of interest regarding the publication of this paper.

\section{References}

[1] Jinap, S., Ilya-Nur, A.R., Tang, S.C., Hajeb, P., Shahrim, K. and Khairunnisak, M. (2010) Sensory Attributes of Dishes Containing Shrimp Paste with Different Concentrations of Glutamate and 5'-Nucleotides. Appetite, 55, 238-244. https://doi.org/10.1016/j.appet.2010.06.007

[2] Yoong, C., Sobhi, B., Mohd, N., Bakar, J., Abdul, R., Shahrim, M., Karim, A. and Ghazali, Z. (2017) Physicochemical Properties and Volatile Profile of Chili Shrimp Paste as Affected by Irradiation and Heat. Food Chemistry, 216, 10-18. https://doi.org/10.1016/j.foodchem.2016.08.011

[3] Kim, Y., Choi, Y., Ku, S., Jang, D., Hasnah, H. and Bong, K. (2014) Comparison of Quality Characteristics between Belacan from Brunei Darussalam and Korean Shrimp Paste. Journal of Ethnic Foods, 1, 19-23. https://doi.org/10.1016/j.jef.2014.11.006

[4] Tambaria, M. and Ambarita, D. (2015) The Influence of Salt and Free Amino Acid Content of Terasi on the Sensory Characteristic of Chili Sauce Added with Terasi. International Conference on Research in Education and Science, Antalya, 23-26 April 2015, , 236-243.

[5] Hajeb, P. and Jinap, S. (2012) Fermented Shrimp Products as Source of Umami in Southeast Asia. Journal of Nutrition and Food Sciences, 1, 1-5.

[6] Mohammad, S., Amin, N., Arshad, A., Bujang, J.S., Siraj, S.S. and Goddard, S. (2009) Reproductive Biology of the Sergestid Shrimp Acetes indicus (Decapoda: Sergestidae) in Coastal Waters of Malacca, Peninsular Malaysia. Zoological Studies, 48, 753-760.

[7] Peralta, E.M., Hatate, H., Kawabe, D., Kuwahara, R., Wakamatsu, S., Yuki, T. and Murata, H. (2008) Improving Antioxidant Activity and Nutritional Components of Philippine Salt-Fermented Shrimp Paste through Prolonged Fermentation. Food Chemistry, 111, 72-77. https://doi.org/10.1016/j.foodchem.2008.03.042

[8] Murwani, R., Putra, H.S.A. and Widiyanto, H. (2016) Shrimp Paste “Terasi” Volatile Compounds from Northern Coast of Central Java. Jurnal Teknologi, 2, 187-192.

[9] Tambaria, M. and Ambarita, D. (2017) The Impact of Indonesian Terasi in the Beef Consomme, a Sensory Assessment. Journal of Biological Sciences, 139, 132-139.

[10] Deshmukh, V.D. (1991) Utilisation of Paste Shrimp Acetes: A Review. Marine Fisheries Information Service, 7-8.

[11] Kleekayai, T., Harnedy, P.A., O’Keeffe, M.B., Poyarkov, A.A., Cunhaneves, A., Suntornsuk, W. and Fitzgerald, R.J. (2015) Extraction of Antioxidant and ACE Inhibitory Peptides from Thai Traditional Fermented Shrimp Pastes. Food Chemistry, 176, 441-447. https://doi.org/10.1016/j.foodchem.2014.12.026

[12] Ramaekers, G., Boesveldt, S., Gort, G., Lakemond, C.M.M., Van Boekel, M.A.J.S. 
and Luning, P.A. (2014) Sensory-Specific Appetite Is Affected by Actively Smelled Food Odors and Remains Stable over Time in Normal-Weight Women. The Journal of Nutrition, 144, 1314-1319. https://doi.org/10.3945/jn.114.192567

[13] Wandestri, Hamzah, F. and Harun, N. (2016) Addition of Some Xantan Gum Concentration on the Quality of Tomato Sauce (Solanum lycopersicum Linn.). J. Faperta, Vol. 3, No. 1.

[14] Torbica, A., Belovi, M., Pestori, M., Skrobot, D. and Dap, T. (2016) Nutritional, Rheological, and Sensory Evaluation of Tomato Ketchup with Increased Content of Natural Fibres Made from Fresh Tomato Pomace. Food and Bioproducts Processing, 98, 299-309. https://doi.org/10.1016/j.fbp.2016.02.007

[15] Irianto, H.E.K.O. and Irianto, G. (2010) Traditional Fermented Fish Products in Indonesia. Food Technol. Dep. Sahid Univ., 67-75.

[16] AOAC (2000) Official Methods of Analysis of Association of Official Analytical Chemists. 17th Edition, AOAC International, Arlington.

[17] Nawas, T., Yousuf, N.B., Azam, S., Ramadhan, A.H., Xu, Y. and Xia, W. (2017) Physiochemical Properties and Sensory Attributes of Ice Cream Fortified with Microencapsulated Silver Carp (Hypophthalmichthys molitrix) Oil. American Journal of Food Science and Nutrition Research, 4, 79-86.

[18] Nielsen, S.S. (2017) Sodium Determination Using Ion-Selective Electrodes, Mohr Titration, and Test Strips. In: Food Analysis Laboratory Manual, Springer International Publishing, Cham, 161-170. https://doi.org/10.1007/978-3-319-44127-6_19

[19] ISO (2003) Microbiology of Food and Animal Feeding Stuffs-Horizontal Method for the Enumeration of Microorganisms-Colony-Count Technique at $30^{\circ} \mathrm{C}$. ISO: 4833. International Standard, Geneva.

[20] International Organization for Standardization International Standard ISO 8589: Sensory Analysis-General Guidance for the Design of Test Rooms. Vol. 2009, 2007.

[21] Sobhi, B., Mohd Adzahan, N., Ab Karim, M. and Karim, R. (2010) Physicochemical and Sensory Properties of a Traditional Chilli Shrimp Paste. 8.

[22] Hassan, M. (2008) Processing of Sambal Belacan. Universiti Putra Malaysia.

[23] Berry, S.K. (2001) Role of Acidulants in Food Industry. Journal of Food Science and Technology, 38, 93-104.

[24] Cho, S.-D. and Kim, G.-H. (2010) Changes of Quality Characteristics of Salt-Fermented Shrimp Prepared with Various Salts. 23.

[25] Li, C., Wu, J., Li, Y. and Dai, Z. (2013) Identification of the Aroma Compounds in Stinky Mandarin Fish (Siniperca chuatsi) and Comparison of Volatiles during Fermentation and Storage. International Journal of Food Science and Technology, 48, 2429-2437.

[26] Pongsetkul, J., Benjakul, S., Sumpavapol, P., Osako, K. and Faithong, N. (2015) Chemical Compositions, Sensory and Antioxidative Properties of Salted Shrimp Paste (Ka-pi) in Thailand. International Food Research Journal, 22, 1454-1465.

[27] Whetstine, M.E.C., Croissant, A.E. and Drake, M.A. (2005) Characterization of Dried Whey Protein Concentrate and Isolate Flavor. Journal of Dairy Science, 88, 3826-3839. https://doi.org/10.3168/jds.S0022-0302(05)73068-X

[28] Kim, I., El-aty, A.M.A., Shin, H., Burm, H., Kim, I. and Shim, J. (2007) Analysis of Volatile Compounds in Fresh Healthy and Diseased Peppers (Capsicum annuum L.) Using Solvent Free Solid Injection Coupled with Gas Chromatography-Flame Ionization Detector and Confirmation with Mass Spectrometry. Journal of Phar- 
maceutical and Biomedical Analysis, 45, 487-494. https://doi.org/10.1016/j.jpba.2007.07.025

[29] Gigot, C., Ongena, M., Fauconnier, M. and Wathelet, J. (2010) The Lipoxygenase Metabolic Pathway in Plants : Potential for Industrial Production of Natural Green Leaf Volatiles. Society for the Environment, 14, 451-460.

[30] Moreno, E., Fita, A., González-mas, M.C. and Rodríguez-burruezo, A. (2012) HS-SPME Study of the Volatile Fraction of Capsicum Accessions and Hybrids in Different Parts of the Fruit. Scientia Horticulturae, 135, 87-97. https://doi.org/10.1016/j.scienta.2011.12.001

[31] Kuda, T., Tanibe, R. and Mori, M. (2009) Microbial and Chemical Properties of aji-no-susu, a Traditional Fermented Fish with Rice Product in the Noto Peninsula, Japan. Fisheries Science, 75, 1499-1506. https://doi.org/10.1007/s12562-009-0175-0

[32] Park, J., Fukumoto, Y., Fujita, E., Washio, T.T.A., Otsuka, T.S., Shimizu, T., Watanabe, K. and Abe, H. (2001) Chemical Composition of Fish Sauces Produced in Southeast and East Asian Countries. Journal of Food Composition and Analysis, 14, 113-125. https://doi.org/10.1006/jfca.2000.0963

[33] Mizutani, T., Kimizuka, A., Ruddle, K. and Ishige, N. (1992) Chemical Components of Fermented Fish Products. Journal of Food Composition and Analysis, 5, 152-159. https://doi.org/10.1016/0889-1575(92)90031-E

[34] Kim, M.-J. and Rhee, H.-S. (1990) Studies on the Changes of Taste Compounds during Soy Paste Fermentation.

[35] Sanjeevan, E., Rathnayake, R.M.U.S.K. and Wadasinghe, A. (2013) Optimization of Chemical Disinfection Conditions to Reduce Microbes in Spice. Products, 1, 238-241.

[36] Sarina, N., Adzahan, M. and Karim, A. (2010) Formulation and Process Improvement for Chili Shrimp Paste Using Sensory Evaluation. International Food Research Journal, 17, 927-935.

[37] Wei, M., Zhou, L., Song, H., Yi, J., Wu, B., Li, Y. and Zhang, L. (2014) Electron Beam Irradiation of Sun-Dried Apricots for Quality Maintenance. Radiation Physics and Chemistry, 97, 126-133. https://doi.org/10.1016/j.radphyschem.2013.11.019

[38] Peter, K.V. (2012) Handbook of Herbs and Spices. Second Edition, Woodhead Pub. Limited, Philadelphia.

[39] Sánchez, M.C., Valencia, C., Gallegos, C., Ciruelos, A. and Latorre, A. (2002) Influence of Processing on the Rheological Properties of Tomato Paste. Journal of the Science of Food and Agriculture, 82, 990-997. https://doi.org/10.1002/jsfa.1141

[40] Koocheki, A., Ghandi, A., Razavi, S., Ali Mortazavi, S. and Vasiljevic, T. (2009) The Rheological Properties of Ketchup as a Function of Different Hydrocolloids and Temperature.

[41] Tilahun, S., Su, D., Hong, M., Geun, I. and Hyeon, S. (2018) Postharvest Biology and Technology Prediction of Lycopene and $\beta$-carotene in Tomatoes by Portable Chroma-Meter and VIS/NIR Spectra. Postharvest Biology and Technology, 136, 50-56. https://doi.org/10.1016/j.postharvbio.2017.10.007

[42] Othman, Z. and Ahmad, Z. (2000) The Potential of Food Irradiation in Malaysia. Malaysian Institute for Nuclear Technology Research, Slangor.

[43] Ossebaard, S.D.V. and Corinne, A. (1996) Amiloride Suppresses the Sourness of $\mathrm{NaCl}$ and LiCl. Physiology \& Behavior, 60, 1317-1322. https://doi.org/10.1016/S0031-9384(96)00258-2

[44] Drake, S.L. and Drake, M.A. (2011) Comparison of Salty Taste and Time Intensity 
of Sea and Land Salts from around the World. Journal of Sensory Studies, 26, 25-34. https://doi.org/10.1111/j.1745-459X.2010.00317.x

[45] Manabe Mariko, O.N., Sane, I. and Tatsuhito, Y. (2009) Improving the Palatability of Salt-Reduced Food Using Dried Bonito Stock. Journal of Food Science, 74, 315-321. https://doi.org/10.1111/j.1750-3841.2009.01283.x

[46] Bellisle, F. (1999) Glutamate and the UMAMI Taste: Sensory, Metabolic, Nutritional and Behavioural Considerations.

[47] Yamaguci Shizuko, N.K. (2000) The Use and Utility of Glutamates as Flavoring Agents in Food. American Society for Nutritional Sciences, 130, 921-926.

[48] Prescott John, S.R.J. (1995) Effects of Oral Chemical Irritation on Tastes and Flavors in Frequent and Infrequent Users of Chili. Physiology \& Behavior, 58, 1117-1127. https://doi.org/10.1016/0031-9384(95)02052-7

[49] Reinbach, H.C., Martinussen, T. and Møller, P. (2010) Effects of Hot Spices on Energy Intake, Appetite and Sensory Specific Desires in Humans. Food Quality and Preference, 21, 655-661. https://doi.org/10.1016/j.foodqual.2010.04.003 